\title{
Sosialisasi dan Pendampingan Pola Asuh Anak Wanita Karir di Perum Citra Permata Sakinah Purwakarta
}

\author{
Sofia Gussevi', Melinda Maulani' ${ }^{2}$, Nur Aeni Muhfi ${ }^{3}$ \\ Program Studi Hukum Keluarga Islam STAI DR. KH. EZ. Muttaqien Purwakarta \\ Posbakum Pengadilan Agama Purwakarta \\ Program Studi Hukum Keluarga Islam STAI DR. KH. EZ. Muttaqien Purwakarta \\ sofiagussevi@gmail.com ${ }^{1}$, melinda.maulan@gmail.com ${ }^{2}$, nuraeni.muhfi@gmail.com ${ }^{3}$
}

DOI: https://doi.org/10.52593/svs.02.1.03

Naskah diterima: 08 November 2021, direvisi: 16 Januari 2022, disetujui: 27

Januari 2022

\begin{tabular}{ll}
\hline Abstract & This service activity is motivated by the researcher's observations regarding \\
\hline Keywords: & career women who leave their children to their parents \\
Woman & (grandmothers/grandparents) and there are also those who hand over the care \\
of their children to people who actually lack knowledge in parenting. Indeed, not & all career women fail in their role as mothers, but the application of parenting \\
in the childcare process is sometimes inappropriate. Actually, both career \\
women and housewives will be successful in raising children if they choose and \\
apply the right parenting pattern. Based on this, this activity aims to provide \\
socialization about child care patterns applied by career women by providing \\
assistance to several families at Perum Citra Permata Sakinah Purwakarta. The \\
results of this activity showed that juvenile delinquency had occurred due to the \\
application of inappropriate parenting. The efforts that have been made in this \\
activity are in the form of deliberation between husband and wife in child care \\
so that undesirable things do not happen to their children.
\end{tabular}

\begin{tabular}{ll} 
Abstrak & \\
\hline Kata kunci: & Kegiatan pengabdian ini dilatarbelakangi dari observasi peneliti mengenai \\
Pola Asuh Anak, & wanita karir yang menitipkan anaknya kepada orang tuanya (nenek/kakek) \\
Wanita Karir & dan ada juga yang menyerahkan pengasuhan anaknya kepada orang yang \\
& sebenarnya kurang ilmu dalam pengasuhan. Memang tidak semua wanita karir \\
& gagal dalam perannya sebagai ibu, tetapi penerapan pola asuh dalam proses \\
& pengasuhan anak kadang yang kurang tepat. Sebenarnya baik wanita karir \\
& ataupun ibu rumah tangga akan berhasil dalam pengasuhan anak jika memilih \\
& dan menerapkan pola asuh yang tepat. Berdasarkan hal tersebut, kegiatan ini \\
& bertujuan untuk memberikan sosialisasi tentang pola asuh anak yang \\
& diterapkan wanita karir dengan melakukan pendampingan terhadap beberapa \\
& keluarga di Perum Citra Permata Sakinah Purwakarta. Hasil dari kegiatan ini \\
& diperoleh bahwa telah terjadi kenakalan remaja disebabkan penerapan pola \\
& asuh anak yang kurang tepat. Adapun upaya yang telah dilakukan dalam \\
& kegiatan ini adalah berupa musyawarah antar suami dan istri dalam \\
& pengasuhan anak agar tidak terjadi hal-hal yang tidak diiginkan pada anak- \\
anak mereka.
\end{tabular}

\section{PENDAHULUAN}

Perkawinan adalah ikatan lahir batin antara seorang pria dan seorang wanita sebagai suami istri dengan tujuan membentuk keluarga atau rumah tangga yang bahagia dan kekal berdasarkan Ketuhanan Yang Maha Esa. Dalam pembentukan suatu keluarga atau rumah tangga akan terlahir anak yang menjadi pelengkap kebahagian dalam perkawinan. Anak yang sah adalah anak yang dilahirkan dalam atau sebagai akibat perkawinan yang sah. Sebagaimana yang dikemukakan dalam Pasal 1 Undang-Undang Nomor 1 Tahun 1974 
Tentang Perkawinan. Lahirnya anak dalam atau akibat dari perkawinan yang sah akan mengakibatkan timbulnya relasi suami, istri dan anak (Sri, 2012).

Orang tua bertanggung jawab untuk memenuhi kebutuhan, mengajari, mengarahkan, dan mendidik anaknya. Tanggung jawab orang tua meliputi tanggung jawab keimanan, materi, fisik, moral, akal, kejiwaan, sosial, dan seks. Tanggung jawab inilah yang disebut bentuk pengasuhan. Tujuan dari pengasuhan itu sendiri adalah untuk membentuk anak menjadi manusia yang sehat, cerdas, berkarakter mulia, berakhlak serta mampu menjadi generasi kuat dan memiliki masa depan yang cerah (Usfitriyah, 2016). Agar semua ini terwujud maka orang tua harus mengetahui dan menerapkan pola asuh yang benar sesuai dengan tahapan perkembangan anaknya yang tentunya berlandaskan hukum Islam yang telah diajarkan oleh Rasulullah dalam berbagai sunnahnya. Orang tualah yang berperan penting untuk mengarahkan kehidupan anak tersebut.

Pengasuhan anak merupakan tanggung jawab orang tua yang dilaksanakan melalui interaksi sehari-hari dalam keluarga. Peran orang tua tidak hanya ibu namun ayah juga sangat berpengaruh dalam mengasuh anaknya, dan hampir setiap waktu anak akan selalu bersama orang tuanya. Hal ini terdapat dalam sabda Rasullullah SAW.: "Seorang lelaki adalah pemimpin dalam keluarganya dan ia bertanggung jawab atas kepemimpinannya. Dan seorang wanita juga pemimpin di rumahnya dan ia bertanggung jawab atas kepemimpinannya." (HR. Al-Bukhari dan Muslim).

Ketika seorang perempuan yang telah berkeluarga dan sudah memiliki anak, kemudian memutuskan untuk berkarir, maka dirinya akan melakukan sebuah peran ganda. Selain memperjuangkan haknya sendiri dalam mencapai sebuah karir, seorang ibu harus juga memikirkan kewajibannya dalam hal mengurus anaknya.

Sumber konflik perkawinan dapat berasal dari status istri yang bekerja. Misalnya ketika pekerjaan di luar rumah dianggap istri sebagai hal penting bagi perkembangan potensinya, sedangkan suami menganggap bahwa kedekatan suami istri akan berkurang dan pengasuhan anak akan terabaikan apabila istri bekerja di luar rumah (Gussevi S. , 2021).

Konflik merupakan masalah yang dapat menyebabkan pertengkaran, perselisihan, atau benturan di antara kedua belah pihak. Jika konflik tidak diatasi sedini mungkin dengan disertai solusi yang baik, maka akan menimbulkan masalah yang jauh lebih buruk dari sebelumnya. Terjadinya konflik dalam rumah tangga merupakan suatu hal yang wajar, dan setiap pasangan suami istri harus memahami dan mengerti faktor penyebab dari konflik tersebut (Gussevi S. , Manajemen Konfik dalam Rumah Tangga Istri yang Bekerja, 2020).

Sebenarnya walaupun istri bekerja namun hubungan antar anggota keluarga tetap harmonis terutama hubungannya dengan suaminya. Hal ini karena keduanya sama-sama bekerja sehingga muncul rasa saling pengertian. Kesibukan istri yang bekerja dalam sektor publik juga tidak menghalangi perhatian mereka terhadap keluarga terutama anak (Gussevi, Tadjudin, \& Amaliah, Sosialisasi dan Pendampingan Dampak Peran Ganda Buruh Perempuan terhadap Kehidupan Rumah Tangga, 2021). Mereka masih memberikan perhatian penuh seperti menyiapkan kebutuhan sekolah anak, menyiapkan sarapan dan membantu anak saat belajar

Hal yang perlu diperhatikan ketika seorang perempuan memiliki karir maka resikonya adalah dia memiliki waktu yang kurang untuk memantau perkembangan anaknya sendiri. Mayoritas perempuan karir yang telah memiliki anak akan menitipkan anaknya pada orang 
yang dia percaya baik dari anggota keluarga lain atau seorang pengasuh. Jika pola asuh anak yang diterapkan oleh ibu yang menjadi wanita karir ini tidak diperhatikan maka akan ada kesenjangan dalam perkembangan anak.

Berdasarkan hal yang demikian, Pengabdian kepada Masyarakat (PkM) ini bermitra dengan Majlis Ta'lim As-Sakinah dalam mengadakan sosialisasi pola asuh anak wanita karir berbentuk penyuluhan, ceramah dengan dialog interaktif serta workshop yang dihadiri oleh masyarakat RT 014 dan RT 015 RW 006 Desa Babakancikao dan RT 013 Desa Kadu Mekar yang merupakan wilayah cakupan Majlis Ta'lim As-Sakinah.

Majlis Ta'lim As-Sakinah merupakan Majlis Ta'lim yang berada di bawah Dewan Kemakmuran Mesjid (DKM) Mesjid As-Sakinah yang terletak di Perum Citra Permata Sakinah. Perum Citra Permata Sakinah ini terdiri dari dua desa yaitu Desa Babakancikao dan Desa Kadumekar. Karena terletak di komplek, maka masyarakat disini lebih individual, apalagi banyak yang bekerja di luar rumah.

Pengasuhan anak merupakan tanggung jawab orang tua yang dilaksanakan melalui interaksi sehari-hari dalam keluarga. Peran orang tua tidak hanya ibu namun ayah juga sangat berpengaruh dalam mengasuh anaknya, dan hampir setiap waktu anak akan selalu bersama orang tuanya. Banyak terjadi permasalahan dalam penerapan pola asuh anak ini, terutama pada keluarga yang orang tuaya sama-sama bekerja. Permasalahan yang terjadi antara lain: 1. Ibu dan ayah bekerja, sementara anak yang masih kecil (balita) dititipkan atau diasuh oleh orang lain yang terkadang pada orang yang tidak cakap melakukan pengasuhan. 2. Ibu dan ayah bekerja, sementara anak melakukan hal yang negatif seperti: merokok, meminum minuman yang memabukkan dan bolos sekolah. 3. Seringkali terjadi pada anak remaja, apabila di rumah sangat patuh kepada orang tuanya, tetapi apabila di berada di lingkungan luar dan bergaul dengan temannya, seperti tidak ada kontrol terhadap dirinya.

Mengacu pada analisis situasi di atas, permasalahan yang dihadapi Majlis Ta'lim AsSakinah sebagai mitra Pengabdian kepada Masyarakat (PkM) dalam usahanya memberikan pemahaman keagamaan kepada masyarakat di antaranya: Pertama, kurangnya minat dan partisipasi masyarakat dalam kegiatan keagamaan yang dilaksanakan oleh Majlis Ta'lim AsSakina; Kedua, sifat warga yang mau menang sendiri dan tidak mau menerima keputusan bersama yang tidak sesuai dengan pendapatnya. Apalagi kalau permasalahan itu berhubungan dengan pemahaman dalam beragama serta organisasi masyarakat yang diikuti oleh warga masyarakat; Ketiga, sifat individual dari warga masyarakat di Perum Citra Permata Sakinah terbilang sangat tinggi, sehingga lebih mengutamakan kepentingan pribadi dibandingkan untuk kepentingan masyarakat secara umum.

Tujuan dari Pengabdian kepada Masyarakat (PkM) ini adalah : Pertama, memberikan pendampingan kepada masyarakat mengenai permasalahan yang terjadi terutama mengenai pola asuh anak yang diterapkan wanita karir; Kedua, berkonstribusi dalam pengimplementasian ilmu dalam pelaksanaan pendampingan, agar mengetahui pehamahaman mereka terkait materi yang disampaikan; Ketiga, target luaran yang diharapkan dalam kegiatan ini adalah sedapat mungkin memberikan nilai manfaat bagi masyarakat mengenai pola asuh anak terutama pada wanita karir.

\section{METODE}

Kegiatan ini menggunakan metode Participatory Research, dimana peneliti terlibat 
langsung dalam proses sosialisasi dan pendampingan kepada keluarga yang ada di Perum Citra Permata Sakinah Purwakarta terhadap istri, suami, anak-anak serta orang-orang yang dianggap sebagai pihak yang turut berpengaruh terhadap pengasuhan anak.

\section{HASIL DAN PEMBAHASAN}

Dalam kegiatan ini, peneliti melakukan sosialisasi dan pendampingan kepada keluarga yang berada di Perum Citra Pemata Sakinah Purwakarta. Perum Citra Permata Sakinah Purwakarta dilingkupi 2 desa yaitu desa Kadu Mekar (RT 013) dan desa Babakancikao (RT 014 dan 015). Untuk lebih jelasnya, maka dikemukakan data mengenai warga Perum Citra Permata Sakinah Purwakarta.

Tabel 1. Data tentang Warga Perum Citra Permata Sakinah Purwakarta

\begin{tabular}{|r|c|c|c|}
\hline No & $\begin{array}{c}\text { Nama Rukun Tetangga } \\
\text { (RT) }\end{array}$ & $\begin{array}{c}\text { Jumlah Kepala Keluarga } \\
\text { (KK) }\end{array}$ & Jumlah Wanita Karir \\
\hline 1. & RT 013 & 100 & 25 \\
\hline 2. & RT 014 & 77 & 23 \\
\hline 3. & RT 015 & 80 & 21 \\
\hline
\end{tabular}

Sumber: Ketua Rukun Tetangga (RT) masing-masing

Berdasarkan data di atas dapat diketahui bahwa $27 \%$ istri yang berada di Perum Citra Permata Sakinah Purwakarta merupakan wanita karir atau bekerja di luar rumah sebagai Pegawai Negeri Sipil (PNS), karyawan swasta dan buruh pabrik. Sebenarnya selain bekerja di luar rumah, banyak juga istri yang bekerja tetapi tetap di rumah seperti buka warung sembako di rumahnya, punya onlineshop, buka usaha kue (home made), dll. Pengabdian kepada masyarakat ini bermitra dengan DKM As-Sakinah, karena anggota majelis ta'limnya melingkupi seluruh ibu-ibu yang berada di Perum Citra Permata Sakinah, maka sasaran dari pengabdian ini tidak hanya kepada istri yang bekerja di luar rumah, tetapi juga melingkupi istri yang bekerja di rumah (buka usaha sendiri) dan ibu rumah tangga. Apalagi sesuai dengan tema dari pengabdian ini mengenai pengasuhan anak, pola asuh anak wanita karir dan yang bukan wanita karir itu sama, cuma yang berbeda dalam pelaksanaan pola asuh anak sebaiknya menyesuaikan dengan karakter anak tersebut.

Dalam kegiatan Pengabdian kepada Masyarakat ini diperoleh data bahwa pola asuh anak yang diterapkan wanita karir di Perum Citra Permata Sakinah, antara lain:

1). Pola asuh otoriter

Pola asuh otoriter cenderung orang tua yang memegang kendali terhadap anak tanpa memikirkan apa yang menjadi keinginan anak dan menganggap orang tua selalu lebih benar dibanding anak. Orang tua terutama ibu melakukan pengawasan, kedisiplinan dan hukuman. 
2). Pola asuh demokratis

Pola asuh demokratis selalu mendengarkan apa yang menjadi keinginan anak tetapi tidak membebaskan anak karena kendali masih berada di tangan orang tua. Orang tua melakukan pengawasan, nasehat dan keteladanan.

Berdasarkan hasil penelitian kedua pola asuh di atas hanya sebagian kecil diterapkan oleh wanita karir di Perum Citra Permata Sakinah Purwakarta.

3). Pola asuh permisif

Sebagian besar wanita karir di kampung Krajan menerapkan pola asuh permisif. Pola asuh permisif adalah jenis gaya pengasuhan yang ditandai oleh tuntutan rendah dengan responsif tinggi. Orang tua yang permisif cenderung sangat mencintai, tapi masih memberikan sedikit panduan dan aturan. Orang tua ini sering kali lebih menempatkan diri sebagai teman ketimbang orang tua.

Pada pola asuh otoriter, orang tua cenderung yang memegang kendali terhadap anak tanpa memikirkan apa yang menjadi keinginan anak dan menganggap orang tua selalu lebih benar dibanding anak. Pada pola asuh demokratis, orang tua selalu mendengarkan apa yang menjadi keinginan anak tetapi tidak membebaskan anak karena kendali masih berada di tangan orang tua. Serta pada pola asuh permisif, orang tua cenderung sangat mencintai tapi memberikan sedikit panduan dan aturan. Pada pola asuh permisif ini orang tua tidak mengharapkan perilaku dewasa dari anak-anak mereka dan sering kali lebih menempatkan diri sebagai teman ketimbang orang tua.

Berdasarkan hasil penelitian, pola asuh anak otoriter dan pola asuh anak demokrasi hanya sebagian kecil diterapkan oleh wanita karir di Perum Citra Permata Sakinah, sebagian besar menerapkan pola asuh anak permisif.

Menurut peneliti, sebenarnya baik pola asuh anak otoriter, pola asuh anak demokrasi maupun pola asuh anak permisif tidak tepat untuk diterapkan tanpa mengetahui karakter anak terlebih dahulu, terlebih pada anak yang ibunya adalah wanita karir seperti di Perum Citra Permata Sakinah Purwakarta yang tidak bisa setiap waktu mengawasi anak. Pola asuh yang baik untuk diterapkan adalah pola asuh yang disesuaikan dengan karakter anak. Oleh sebab itu, baik ibu yang bekerja ataupun ibu rumah tangga, dalam menerapkan pola asuh anak ini diharapkan mengetahui karakter anaknya terlebih dahulu.

Keluarga sebagai basis terdepan dalam membina pribadi dan masyarakat, baik dan buruknya seseorang akan berbanding lurus dengan pembinaan yang dilakukan dalam lingkup keluarga. Orang tua memiliki peran sentral, karena orang tua sesungguhnya merupakan madrasatul ula. Orang tua terutama ibu menjadi sekolah pertama bagi anaknya. Pendidikan yang diperoleh seorang anak dalam lingkungan keluarga merupakan pendidikan yang paling utama, karena peranan orang tua dalam mempengaruhi pembentukan karakter seorang anak (Gussevi \& Muhfi, Tantangan Mendidik Generasi Milenial Muslim di Era Revolusi Industri 4.0, 2021).

Mengenai karakter ini, ada tiga karakter anak yaitu: 
1) Karakter anak mudah (easy child)

Anak dengan pembawaan ini biasanya ceria, aktif, mudah mengahadapi perubahan, dan biasanya sangat menyukai orang-orang dan siyuasi baru, tidak mudah marah, tapi juga bukan tipe penurut. Untuk mengasuh anak tipe ini harus berhati-hati, tarik ulur peraturan adalah hal yang wajib diterapkan, agar tidak terkekang di satu sisi namun tetap terkendali. Cobalah sering meluangkan waktu untuk benar-benar berbicara tentang kesehariannya.

2) Karakter anak selalu butuh pemanasan (slow to warm up)

Perasaan anak dengan tipe ini sangatlah halus, sebaiknya dijauhkan dengan kritik yang sangat tajam dan kasar. Penolakan pada dirinya akan membuatnya menjadi seorang penakut dan rapuh sepanjang hidupnya. Orang tua wajib untuk memastikan perkembangan personalitasnya stabil dan memiliki waktu perubahan situasi yang cukup.

3) Karakter anak sulit (difficult child)

Tipe anak ini, mereka penuh energ dan semangat, sehingga seolah sukar dikendalikan. Emosinya mudah untuk naik namun mudah juga untuk turun. Mereka lebih aktif, lebih tidak sabaran, lebih suka menantang/membantah, tapi di satu sisi mereka juga lebih sensitif dan mudah rapuh. Solusi terbaik untuk anak tipe ini hanyalah satu, membuatnya terus aktif sepanjang hari. Ajak main di luar, pilihlah sekolah dengan aktifitas belajar di luar ruangan.

Kemudian dalam kegiatan Pengabdian kepada Masyarakat ini juga diperoleh data mengenai dampak pola asuh anak yang diterapkan wanita karir di Perum Citra Permata Sakinah, antara lain:

1) Dampak pola asuh anak otoriter

Dengan penerapan pola asuh otoriter ini, komunikasi atau hubungan antara orang tua dan anak cenderung renggang. Terbiasa dengan aturan dan saksi jika melakukan kesalahan, sehingga menimbulkan kurangnya percaya diri pada anak dalam melakukan sesuatu, lebih pendiam bahkan akan sulit beradaptasi dengan tempat baru dan bersosialisasi dengan orang-orang yang baru dikenalnya. Dampak positif dari pola asuh ini yaitu dapat menjadikan anak lebih penurut dan mudah diatur serta lebih sopan dalam bertingkah laku dan melakukan berbagai hal.

2) Dampak pola asuh permisif

Pola asuh permisif ini tidak disertai dengan batasan yang jelas dari orang tua. Orang tua cenderung menerima atau mengikuti apapun keinginan dan perilaku anak. Anak yang dibesarkan dengan pola asuh yang permisif ini akan memiliki risiko menjadi anak yang kurang bisa mengontrol diri. Meskipun begitu, pola asuh jenis ini baik diterapkan ketika orang tua ingin mengembangkan kecerdasan seni dan imajinasi anak. Sebab, imajinasi anak akan berkembang dengan baik bila orang tua tak terlalu membatasinya. Tak cuma itu saja, dampak positif dari pola asuh ini juga bisa membuat anak jadi lebih kreatif.

3) Dampak pola asuh demokratis

Pola asuh demokratis sangat menguntungkan bagi orang tua maupun anak, karena pola asuh ini membuat komunikasi antara orang tua dan anak tetap terjaga. Pola demokratis sangat cocok diterapkan pada generasi milenial karena anak merasa bebas namun orang tua harus memberikan aturan yang jelas agar anak bisa bertanggung jawab 
atas apa yang dilakukan. Pola asuh ini sebenarnya lebih memberikan dampak positif terhadap anak dibandingkan pola asuh yang lainnya

Pola asuh anak otoriter mempunyai dampak negatif yaitu hubungan antara orang tua dan anak cenderung renggang, karena orang tua tidak mau untuk mendengarkan pendapat atau kemauan anaknya. Terbiasa dengan aturan dan sanksi jika melakukan kesalahan, dapat menimbulkan kurangnya percaya diri pada anak dalam melakukan sesuatu bahkan akan sulit beradaptasi dengan tempat baru dan bersosialisasi dengan orang-orang yang baru dikenalnya. Tetapi juga ada dampak positifnya yaitu anak lebih penurut dan mudah diatur serta lebih sopan dalam bertingkah laku dalam melakukan berbagai hal.

Sedangkan pola asuh permisif mempunyai dampak negatif yaitu anak yang kurang bisa mengontrol diri. Mereka juga terkadang tidak bisa bertanggung jawab atas perilakunya. Pasalnya, pola asuh permisif ini tidak disertai dengan batasan yang jelas dari orang tua. Di sini orang tua cenderung untuk menerima atau mengikuti apapun keinginan dan perilaku anak. Meskipun begitu, pola asuh jenis ini baik diterapkan ketika orang tua ingin mengembangkan kecerdasan seni dan imajinasi anak. Sebab, imajinasi anak akan berkembang dengan baik bila orang tua tak terlalu membatasinya. Tak cuma itu saja, dampak positif dari pola asuh ini juga bisa membuat anak jadi lebih kreatif.

Dalam pola asuh permisif ini orang tua biasanya memberikan tuntutan yang minim kontrol atas perilaku anak. Jika anak melakukan kesalahan, orang tua dengan pola asuh ini jarang, bahkan tidak pernah memberikan hukuman. Oleh sebab itu, pola asuh permisif bisa membuat anak menjadi suka memberontak, suka mendominasi, dan tidak jelas arah hidupnya. Pola asuh permisif orang tua memang bisa membuat hubungan antara orang tua dan anak memiliki tingkat kehangatan yang tinggi, tetapi kurang kontrol dari orang tua. Inilah yang nantinya bisa membuat anak menjadi manja, egois, tidak disiplin, dan mudah menyerah.

Terakhir pola asuh demokratif ditandai dengan kebebasan yang diberikan orang tua, anak bisa mengerti lingkungan sekitarnya seperti apa, situasinya bagaimana. Jika anak sudah tahu keadaan sekelilingnya anak akan lebih waspada terhadap diri dan pergaulannya. Pola asuh demokratis sangat menguntungkan bagi orang tua maupun anak, karena pola asuh ini membuat komunikasi antar orang tua dan anak tetap terjaga. Pola demokratis sangat cocok diterapkan pada generasi milenial karena anak merasa bebas namun orang tua harus memberikan aturan yang jelas agar anak bisa bertanggung jawab atas apa yang dilakukannya.

Dengan demikian, menurut peneliti yang perlu diperhatikan orang tua adalah adanya komunikasi yang baik dan pembahasan yang mendalam berkaitan dengan pola asuh anak yang mau diterapkan oleh suami istri ketika istri ikut bekerja dan menjadi wanita karir. Salah satunya mengenai orang yang yang akan mengasuh anak ketika suami dan istri bekerja di waktu bersamaan. Kemudian selalu melakukan pemantauan terhadap anak dengan menjalin komunikasi yang baik dengan anak maupun dengan pengasuh. Komunikasi yang baik dengan anak dapat dilakukan dengan menjelaskan apa yang anak tanyakan tentang kesibukan yang dilakukan orang tua sehingga tidak memiliki banyak waktu dengan anak. Kemudian orang tua terutama ibu juga hendaknya menyempatkan waktu untuk berinteraksi dengan anak di 
tengah kesibukan sehingga anak merasakan kedekatan emosional dengan orang tua. Selanjutnya, hendaknya ibu selalu menambah pengetahuan tentang masalah parenting anak dengan membaca buku, mengikuti seminar, dan mencari informasi yang berkaitan tentang parenting anak.

Hal terpenting yang harus disadari dan diberikan kepada anak-anak adalah pendidikan kedisiplinan, sopan santun, dan budi pekerti sedini mungkin. Kita pasti ingin anak-anak kita memiliki pribadi yang berkualitas yang tidak cukup hanya memiliki kecerdasan IQ (Intelligence Questients) yang tinggi. Fakta membuktikan bahwa kecerdasan emosi atau EQ (Emotional Questients) berperan sangat penting dalam menopang keberhasilan seseorang (Masitoh, Gussevi, \& Tabroni, 2021). Tidak mudah mengarahkan anak kepada pengembangan potensi terbaiknya, sementara kita pada saat yang sama ibu yang bekerja sebagai wanita karier hanya memiliki sedikit waktu untuk berinteraksi dengan anak-anak mereka. Ibu yang bekerja harus menunjukkan kepada anak-anak mereka bahwa dia tidak perlu merasa bersalah karena kesibukan dalam bekerja. Memberikan pengertian bahwa mereka adalah harta yang begitu berharga. Walaupun kuantitas pertemuan dengan anak-anak sedikit, tapi kondisinya harus selalu menyenangkan dan berkualitas. Jika demikian suasananya, niscaya anak kita bisa menerima pilihan kita dengan baik. Jadi kita tidak perlu merasa bersalah hanya karena telah meninggalkan mereka untuk bekerja, dan yang mereka perlukan adalah seorang ibu yang senantiasa memelihara akhlaknya pada setiap ucapan dan perbuatannya, dan ia berupaya semaksimal mungkin agar akhlak Islam ini selalu menghiasi dirinya dalam berinteraksi dengan anak-anak mereka, karena anak-anak yang berusia sangat mudah untuk mengikuti dan meniru perilaku seorang ibu. Jadi seorang ibu hendaknya selalu menjadi suri tauladan yang baik bagi anak-anaknya dalam melaksanakan ibadah sehari-hari. Dan yang paling penting sesibuk apapun aktifitas seorang ibu hendaknya selalu memantau tingkah laku anak-anaknya.

\section{KESIMPULAN}

Masyarakat Perum Citra Permata Sakinah sebagai penerima manfaat dari kegiatan Pengabdian kepada Masyarakat (PkM) setelah mendapatkan pendampingan, masyarakat mengetahui pola asuh anak yang di terapkan oleh wanita karir yaitu pola asuh permisif, demokratis dan otoriter. Pola asuh anak otoriter dan pola asuh anak demokrasi hanya sebagian kecil diterapkan oleh wanita karir, tetapi sebagian besar menerapkan pola asuh anak permisif. Mengenai dampak pola asuh yang diterapkan oleh wanita karir, masingmasing pola asuh mempunyai dampak baik negatif maupun dampak positif. Dampak negatif pola asuh otoriter pada anak adalah tidak terbuka pada orang tua dan kurang percaya diri, tetapi dampak positifnya yaitu dapat menjadikan anak lebih penurut dan mudah diatur serta lebih sopan dalam bertingkah laku. Dampak negatif pola asuh permisif pada anak adalah anak kurang bertanggung jawab dan tidak dapat mengontrol emosi tetapi dampak positifnya yaitu cocok untuk mengembangkan kecerdasan seni dan imajinasi anak serta bisa membuat anak jadi lebih kreatif. Terakhir dampak pola asuh demokratis menjadikan komunikasi antara orang tua dan anak lebih terjaga.

Setelah mengikuti kegiatan Pengabdian kepada Masyarakat (PkM) ini diharapkan masyarakat dapat mengimplementasikan pengetahuan yang didapat dari kegiatan ini dalam 
mengatasi permasalahan dalam rumah tangga terutama mengenai pengasuhan anak. Masyarakat sangat antusias mengikuti kegiatan, terlihat dari banyaknya peserta yang mengikuti kegiatan ini.

\section{UCAPAN TERIMA KASIH}

Penulis mengucapkan terima kasih kepada ketua dan pengurus Dewan Kemakmuran Mesjid (DKM) As-Sakinah yang telah menyediakan waktu, tempat, tenaga dan pikirannya untuk ikut dalam kegiatan pengabdian ini. Juga kepada segenap keluarga besar sivitas akademika Program Studi Hukum Keluarga Islam termasuk Himpunan Mahasiswa Jurusan (HMJ) yang ikut serta mensukseskan kegiatan pengabdian. Serta kepada STAI DR. KH. EZ. Muttaqien yang telah memberi dukungan finansial dalam penyelenggaraan kegiatan ini.

\section{DAFTAR PUSTAKA}

Gussevi, S. (2020). Manajemen Konfik dalam Rumah Tangga Istri yang Bekerja. Muttaqien, 56-73.

Gussevi, S. (2021). Sosialisasi dan Pendampingan Manajemen Konflik dalam Rumah Tangga Istri yang Bekerja di Perum Citra Permata Sakinah Purwakarta. Sivitas, 0109.

Gussevi, S., \& Muhfi, N. A. (2021). Tantangan Mendidik Generasi Milenial Muslim di Era Revolusi Industri 4.0. Paedagogie, 46-57.

Gussevi, S., Tadjudin, A., \& Amaliah, F. T. (2021). Sosialisasi dan Pendampingan Dampak Peran Ganda Buruh Perempuan terhadap Kehidupan Rumah Tangga. Sivitas, 53-60.

Masitoh, S., Gussevi, S., \& Tabroni, I. (2021). Peran Wanita Karir dalam Pendidikan Anak. Paedagogie, 109-123.

Sri, L. (2012). Psikologi Keluarga. Jakarta: Prenandamedia Group.

Usfitriyah. (2016). Islamic Parenting (Pengasuhan Anak dalam Islam). Jakarta: Kompas. 